\title{
In vitro Antibacterial Activity of Alkaloids Isolated from Leaves of Eclipta alba Against Human Pathogenic Bacteria
}

\author{
Swapna Gurrapu and Estari Mamidala*
}

\section{Swapna Gurrapu and Estari Mamidala*}

Infectious Diseases Research Lab, Department of Zoology, Kakatiya University, Warangal-506009, telangana State, INDIA.

\section{Correspondence}

Estari Mamidala; Infectious Diseases Research Lab, Department of Zoology, Kakatiya University, Warangal-506009, telangana State, INDIA

Phone number: 9848309231

E-mail: drestari@kakatiya.ac.in

\section{History}

- Submission Date: 19-05-2017;

- Review completed: 23-05-2017;

- Accepted Date: 30-05-2017.

\section{DOI : 10.5530/pj.2017.4.91}

Article Available online http://www.phcogj.com/v9/i4

\section{Copyright}

(C) 2017 Phcog.Net. This is an openaccess article distributed under the terms of the Creative Commons Attribution 4.0 International license.

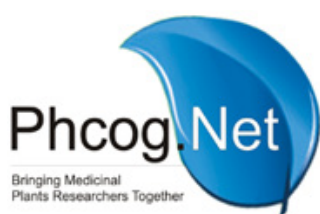

\begin{abstract}
The susceptibility of five human pathogenic bacterial species to an alkaloids isolated from the leaves of this plant was screened using the agar well diffusion and broth micro-dilution assay. The purity of isolated alkaloids was checked by TLC and qualitative phytochemical analysis and total alkaloids were quantified. In the present study, the inhibitory action of the alkaloid was found to increase with an increase in concentration against all bacterial strains. The maximum zone of inhibition was observed at the concentration of $500 \mathrm{\mu g} / \mathrm{ml}$ against all the bacteria. In this study, the $S$. aureus and $E$. coli are the more susceptible than the other selected human pathogenic bacteria. Based on the observations, E. alba appears to be a valuable source for antimicrobial properties and helps to produce antimicrobial agents to treat human pathogenic infections. Context: Different parts of Eclipta alba crude extracts are used traditionally for the treatment of several diseases of liver, skin and stomach. Aims: To study the in vitro antimicrobial activity of alkaloids isolated from $E$. alba against human pathogenic bacteria. Settings and Design: The susceptibility of five human pathogenic bacterial species to an alkaloids isolated from the leaves of this plant was screened using the agar well diffusion and broth micro-dilution assay. Methods and Material: The purity of isolated alkaloids was checked by $T L C$ and qualitative phytochemical analysis and total alkaloids were quantified. Agar-well diffusion and Broth micro-dilution methods were selected to assess the antimicrobial activity. Statistical analysis used: One-way analysis of variance (ANOVA) was used to determine statistical significance. Results: In the present study, the inhibitory action of the alkaloid was found to increase with an increase in concentration against all bacterial strains. The maximum zone of inhibition was observed at the concentration of $500 \mu \mathrm{g} / \mathrm{ml}$ against all the bacteria. In this study, the $S$. aureus and E. coli are the more susceptible than the other selected human pathogenic bacteria. Conclusion: Based on the observations, E. alba appears to be a valuable source for antimicrobial properties and helps to produce antimicrobial agents to treat human pathogenic infections
\end{abstract}

Key words: Eclipta alba, Alkaloid, Human pathogenic bacteria, Antimicrobial activity, Agarwell diffusion, Broth micro-dilution assay.

Key Messages: The results of the present study support the medicinal usage of the alkaloids isolated from the leaves of E. alba can be subjected to identification and isolation of the therapeutic antimicrobials and undergo further pharmacological screening that can be used as sources for new drugs.

\section{INTRODUCTION}

In the modern medicinal system, people have started looking at the ancient healing systems like Ayurveda, Siddha and Unnani due to the adverse effects associated with synthetic drugs. Especially in developing countries, herbal drugs play an important role in health care programs. The remarkable broad definition for medicinal plants was incorporated by the ancient Indian literature and it considered all plant parts to be potential sources of medicinal components. ${ }^{1}$ A diverse array of chemicals are synthesized by medicinal plants. In hepatic and spleen enlargement Eclipta alba is used as a tonic and diuretic and it is also used for catarrhal jaundice and for skin diseases. ${ }^{2}$ Plant-derived traditional medicines can be used to treat different diseases as they contain a vari- ety of secondary metabolites to which the bacterial species may not be resistant.

The plant Eclipta alba (L.) is commonly known as false daisy which is annual herbaceious and belonging to Asteraceae family. The leaves of this plant are opposite, lanceolate and sessile. The plant is an erect, roughly hairy, annual, much branched and rooting at the nodes. It is also known as Bhringaraj and Karisilakanni, which is found a common weed throughout India ascending up to $6000 \mathrm{ft}$. E. alba has been used in various parts of tropical and sub-tropical regions like south America, Asia, Africa. The plant is commonly used in hair oil all over India for healthy black and long hair. ${ }^{3}$ This plant is well documented and several in vitro and in vivo studies describe its anti-ageing 
agent and anti-hepatotoxic properties. ${ }^{4}$ Coumestans like wedelolactone, desmethyl wedelolactone, ${ }^{5}$ furano-coumarins, ecalbatin, ${ }^{6}$ eleanane \& taraxastane glycosides, ${ }^{7,8}$ are the consisting main active principles in $E$. alba. The safety, efficacy and quality of some of bioactive principles have not been scientifically validated and antibacterial activity was also not studied for isolated phytochemicals present in it. Therefore the objective of this present study is to study the antimicrobial activity of alkaloids isolated from the leaves of E. alba plant.

\section{MATERIALS AND METHODS}

\section{Plant material and alkaloids extraction}

Leaves of E. alba were collected in Kakatiya University Campus in July 2016. The plant was botanically authenticated by Prof. V.S. Raju, Senior Taxonomist at Department of Botany, Kakatiya University, India. The collected sample was grinded and this ground sample (500 g) was made alkaline with 30\% ammonia and extracted with chloroform at room temperature for a total period of $24 \mathrm{~h}$. The extract was partitioned between chloroform and $5 \% \mathrm{HCl}$. Finally chloroform was totally evaporated from the organic phase to form the alkaloid powder (5.2 gm).

\section{Thin layer chromatography (TLC)}

To determine the purity and relative to front (Rf) of isolated compound, a thin layer chromatography was carried out as per conventional one dimensional ascending method using silica gel 60F254, 7x6 cm (Merck) were cut with ordinary household scissors. Plate marking were made with soft pencil. Glass capillaries were used to spot the sample for TLC. Applied $1 \mu \mathrm{l}$ of extract by using capillary at distance of $1 \mathrm{~cm}$. After presaturation with mobile phase (chloroform:methanol- 0.5:9.5) for $20 \mathrm{~min}$ utes the plates were dried and the spot which appeared were developed with iodine vapour. The movement of sample was expressed by its retention factor ( $\mathrm{Rf}$ ) and values were calculated as: $\mathrm{Rf}=$ Distance travelled by the solute/Distance travelled by solvent front TLC plates

\section{Qualitative Determination of Phytochemicals}

Qualitative phytochemical analyses of the isolated alkaloid were performed by following the protocol of J.B. Harborne (1973). ${ }^{9}$

Tannins: $200 \mathrm{mg}$ of plant material was boiled in $10 \mathrm{~mL}$ distilled water and few drops of $\mathrm{FeCl}_{3}$ were added to the filtrate; a blue-black precipitate indicated the presence of Tannins.

Alkaloids: $200 \mathrm{mg}$ plant material was boiled in $10 \mathrm{~mL}$ methanol and filtered. $1 \% \mathrm{HCl}$ was added than 6 drops of Dragendorff reagent was added, and brownish-red precipitate was the indication for the presence of alkaloids.

Saponins (Frothing test): $5 \mathrm{~mL}$ distilled water was added to $200 \mathrm{mg}$ plant material. $0.5 \mathrm{~mL}$ filtrate was diluted to $5 \mathrm{~mL}$ with distilled water and shaken vigorously for 2 minutes. Formation of stable foam indicates the presence of saponins.

Cardiac Glycosides (Keller-Kiliani test): $2 \mathrm{~mL}$ filtrate was treated with $1 \mathrm{~mL}$ glacial acetic acid containing few drops of $\mathrm{FeCl}_{3}$. Conc. $\mathrm{H}_{2} \mathrm{SO}_{4}$ was added to the above mixture giving green-blue colour depicting the positive results for presence of cardiac glycosides.

Steroids (Liebermann-Burchard reaction): To $10 \mathrm{~mL}$ chloroform 200 mg plant material was added. In the ratio of $1: 1$, Acetic anhydride was added which resulted into the formation of blue-green ring pointing towards the presence of steroids.

Terpenoids (Salkowski test): $2 \mathrm{~mL}$ of chloroform $\left(\mathrm{CHCl}_{3}\right)$ and $3 \mathrm{~mL}$ of concentrated sulphuric acid $\left(\mathrm{H}_{2} \mathrm{SO}_{4}\right)$ were carefully added to $200 \mathrm{mg}$ plant material. A reddish brown colouration signified the presence of terpenoids.
Flavonoids: To the aqueous filtrate $5 \mathrm{~mL}$ of dilute ammonia solution was added, followed by concentrated $\mathrm{H}_{2} \mathrm{SO}_{4}$. A yellow colouration indicated the presence of flavonoids.

Anthraquinones: $500 \mathrm{mg}$ of dried plant leaves were boiled in $10 \% \mathrm{HCl}$ for 5 mins and filtrate was allowed to cool. Few drops of $10 \% \mathrm{NH}_{3}$, qual volume of $\mathrm{CHCl}_{3}$ was added to $2 \mathrm{~mL}$ filtrate. The formation of rose-pink colour implies the presence of Anthraquinones.

Reducing Sugars: To the $10 \mathrm{~mL}$ of aqueous extract a few drops of Fehling's solution A and B were added; an orange red precipitate suggests the presence of reducing sugars.

\section{Quantitative Determination of alkaloids}

The content of alkaloids was measured by following the protocol described by Harborne (1984) ${ }^{10}$ To prepare the suspension, dispersing $5 \mathrm{gm}$ of the dried leaves in $10 \%$ acetic acid solution in ethanol and kept at $28^{\circ} \mathrm{C}$ for $4 \mathrm{hrs}$ which was further filtered through Whatman Number 42. Alkaloid was precipitated by concentrating the filtrate to one quarter of its original volume and then drops of conc. aqueous $\mathrm{NH}_{4} \mathrm{OH}$ were added. Finally the precipitate was washed with $1 \%$ ammonia solution and dried at $80^{\circ} \mathrm{C}$ in the oven. The alkaloid content alkaloid was calculated and expressed as $\mathrm{mg} / \mathrm{gm}$ of sample.

\section{Bacterial Cultures}

Clinical isolates of Escherichia coli, Pseudomonas aeruginosa, Shigella boydii, Staphylococcus aureus and Streptococcus faecalis were obtained from the Department of Microbiology, Kakatiya University, Telangana State, India. On nutrient agar slopes (Hi-media) all the test strains were maintained and were sub-cultured once in every two-week. These bacteria served as test pathogens for antibacterial activity assay.

\section{Antibacterial assays}

\section{Agar-well diffusion}

The assay was conducted as described by Perez et al. (1990). Briefly, on nutrient agar microorganisms from growth are incubated at $37^{\circ} \mathrm{C}$ for 18 $\mathrm{h}$ and were suspended in saline solution $0.85 \% \mathrm{NaCl}$. To inoculate the suspension $90 \mathrm{~mm}$ diameter petri plates with a sterile non-toxic cotton swab on a wooden applicator was used. In the agar six mm diameter wells were punched and filled with $50 \mu \mathrm{L}$ of different concentration $(125$, 250 and $500 \mu \mathrm{g} / \mathrm{ml}$ ) of alkaloid sample. According to our control experiments, $1 \%(\mathrm{v} / \mathrm{v})$ DMSO dissolution of the alkaloids was aided which did not affect the growth of microorganisms. Ciproflaxacin antibiotic was used as positive reference standard to determine the sensitivity of the strains. Discs were directly placed onto the bacterial culture and then the plates were incubated in air at $37^{\circ} \mathrm{C}$ for $24 \mathrm{~h}$. Antibacterial activities were evaluated by measuring inhibition zone diameters. The experiments were conducted twice.

\section{Broth microdilution assay}

To determine the minimal inhibitory concentrations (MIC) of isolated alkaloids against the selected test microorganisms broth microdilution method was used and this was recommended by the National Committee for Clinical Laboratory Standards. ${ }^{11}$ The tests were performed in 96 well-plates. In 1\% DMSO the alkaloids were dissolved and were transferred in plates to obtain a twofold serial dilutions ranging from 10 to $640 \mu \mathrm{g} / \mathrm{ml}$. Then the plates were inoculated with microbial suspensions and diluted to have $10^{5} \mathrm{cfu} / \mathrm{ml}$ in each well. The final volumes in wells were $200 \mu \mathrm{l}$. MIC was recorded after $24 \mathrm{~h}$ incubation in air at $37^{\circ} \mathrm{C}$, as a lowest extract concentration demonstrating no visible growth in the broth. 


\section{Statistical analysis}

Values are expressed as mean \pm SE. One-way analysis of variance (ANOVA) was used to determine statistical significance and values with $p<0.05$ were considered significant.

\section{RESULTS AND DISCUSSION}

\section{Phytochemical Profiling}

The present study was carried to investigate the presence of medicinally important phytochemical (alkaloids) in E. alba. The qualitative test which describes the appearance of alkaloid is listed in the Table 1 and was isolated from the leaves of E. alba. In this study we checked whether other phytochemicals present or not and these results noted that, the absence of tannins, saponins, flavonoids, terpenoids, carotenoids, cardiac glycosides, and reducing sugars. The presence of different phytochemicals and the antimicrobial activity of ethanolic, petroleum ether and methanolic extracts of $E$. alba have been previously reported. ${ }^{12} \mathrm{How}-$ ever, our study is first ever report to the best of our knowledge on antibacterial activity of alkaloid from E. alba in India. The purity of alkaloids were confirmed by performing TLC which shows the appearance of one spot using solvent system chloroform: methanol (0.5:9.5). The Rf value of the peak was 0.81 .

The quantitative phytochemical estimation specifies that the leaves of E. alba contain a significant amount of alkaloid content. The alkaloids content was quantitatively estimated and was found in the range of 0.4 $\mathrm{mg} / \mathrm{gm}$. Earlier reports on quantitative yield also revealed that E. alba contained highest quantity of alkaloids as compared to other medicinal plants. ${ }^{12-14}$ Simple phenols and phenolic acids, quinones, flavones, flavonoids and flavonols, tannins, coumarins, alkaloids, terpenoids and essential oils, lectins and polypeptides are the major groups of antimicrobial compounds. ${ }^{15}$

\section{Antibacterial Study}

The antibacterial activity of isolated alkaloidal compound was determined by using agar well diffusing methods. The results in Table 2 show that the isolated compound has good antibacterial activity against selected human pathogenic bacteria. In the present study, the inhibitory action of the alkaloid was found to increase with an increase in concentration against all bacterial strains. The tested bacterial strains showed different patterns of inhibition. This was supported by an earlier study on an alcoholic extract that exhibited greater activity than the aqueous and hexane extracts against bacteria, with no cellular toxicity. ${ }^{16}$ The broad spectrum of antibacterial activity was reported for E. alba. ${ }^{17,18}$
The isolated alkaloid compound at a concentration of $500 \mu \mathrm{g} / \mathrm{disc}$ showed maximum inhibition against $S$. aureus $(16.5 \mathrm{~mm})$, followed by E. coli (14.7 mm), S. boydii (13.2 $\mathrm{mm})$, S. faescalis $(12.5 \mathrm{~mm})$ and P. aeruginosa. $(9.8 \mathrm{~mm})$ by broth dilution method. The maximum zone of inhibition was observed at the concentration of $500 \mu \mathrm{g} / \mathrm{ml}$ against all the bacteria.

E. alba leaves methanolic extract showed maximum activity against gram-negative bacteria and showed the highest inhibition zones against P. aeruginosa and E. coli. ${ }^{19}$ This study confirms the presence of the alkaloid compounds may be responsible for the antibacterial activity against various bacterial strains.

The varying concentrations between 10 to $640 \mathrm{ug} / \mathrm{ml}$ of the isolated alkaloid compound of E. alba were tested in order to determine their MICs. The MICs of the isolated alkaloid compound against the five tested bacterial is presented in Table 3. The lowest MICs were obtained in the alkaloid compound having $42 \mu \mathrm{g} / \mathrm{ml}$ against $E$. coli, $57 \mu \mathrm{g} / \mathrm{ml}$ against $S$. aureus, $61 \mu \mathrm{g} / \mathrm{ml}$ against $S$. boydii, $82 \mathrm{ug} / \mathrm{ml}$ against $P$. aeruginosa and 89 $\mu \mathrm{g} / \mathrm{ml}$ against $S$. faescalis. The MIC ranged from 10 to $640 \mu \mathrm{g} / \mathrm{ml}$ for all studied microorganisms while for ciprofloxacin it ranged from 0.1 to 10 $\mu \mathrm{g} / \mathrm{ml}$. These alkaloids known to be biologically active as well as showing antimicrobial activities. In this study, the S. aureus and E. coli are the more susceptible than the other selected human pathogenic bacteria. In this study, this antimicrobial activity may be due to the presence of $(\mathrm{OH})$ group in the structure isolated alkaloids which increased the activity to inhibit the bacterial growth by changing the nature of cell protein (denaturation), thus increasing the permeability of cell membranes, ${ }^{20}$

Table 1 : The qualitative chemical analysis for the isolated alkaloids of E. alba

\begin{tabular}{cc}
\hline Phytochemical test & Results \\
\hline Tannins (Folin-Denis test) & - \\
Alkaloids (Dragendorff test) & + \\
Saponins (Frothing test) & - \\
Cardiac Glycosides (Keller-Kiliani test) & - \\
Steroids (Liebermann-Burchard reaction) & - \\
Terpenoids (Salkowski test) & - \\
Flavonoids (Pb acetate test) & - \\
Anthraquinones (Colour test) & - \\
Reducing Sugars (Fehling's test) & - \\
\hline
\end{tabular}

Table 2: The zone of inhibition produced by alkaloid compounds isolated from E. alba against human pathogenic bacteria

\begin{tabular}{|c|c|c|c|c|c|}
\hline \multirow[b]{2}{*}{ Bacteria Strains } & \multicolumn{5}{|c|}{ Inhibition zone (mm) } \\
\hline & $\begin{array}{c}125 \\
\mu \mathrm{g} / \mathrm{ml}\end{array}$ & $\begin{array}{c}250 \\
\mu \mathrm{g} / \mathrm{ml}\end{array}$ & $\begin{array}{c}500 \\
\mu \mathrm{g} / \mathrm{ml}\end{array}$ & $\begin{array}{c}\text { Standard (Ciprofloxacin, } \\
25 \mu \mathrm{g} / \text { disc) }\end{array}$ & Control (DMSO) \\
\hline Escherichia coli & $11.0 \pm 0.03$ & $11.4 \pm 0.03$ & $14.7 \pm 0.01^{*}$ & $20.3 \pm 0.07$ & 0 \\
\hline Pseudomonas aeruginosa & $0.00 \pm 0.00$ & $9.0 \pm 0.01$ & $9.8 \pm 0.05$ & $10.5 \pm 0.06$ & 0 \\
\hline Shigella boydii & $10.2 \pm 0.06$ & $10.5 \pm 0.00$ & $13.2 \pm 0.02^{*}$ & $11.2 \pm 0.07$ & 0 \\
\hline Staphylococcus aureus & $12.5 \pm 0.02$ & $13.3 \pm 0.01$ & $16.5 \pm 0.02^{*}$ & $23.5 \pm 0.12$ & 0 \\
\hline Streptococcus faecalis & $9.7 \pm 0.07$ & $10.0 \pm 0.02$ & $12.5 \pm 0.06^{*}$ & $20.6 \pm 0.13$ & 0 \\
\hline
\end{tabular}

Values are expressed as mean \pm SEM and analyzed by one-way analysis of variance (ANOVA) followed by Dennett's $t$ test; $* P<0.05$; 
Table 3: Antibacterial activity of alkaloid compounds isolated from $E$. alba against selected human pathogenic bacteria by minimum inhibitory concentration (MIC) method

\begin{tabular}{cccc}
\hline Bacterial strains & $\begin{array}{c}\text { MICs }(\mu \mathrm{g} / \mathrm{ml}) \text { of } \\
\text { isolated alkaloid } \\
\text { compound }\end{array}$ & $\begin{array}{c}\text { Standard } \\
\text { (Ciprofloxacin) }\end{array}$ & $\begin{array}{c}\text { Control } \\
\text { (DMSO) }\end{array}$ \\
\hline $\begin{array}{c}\text { Escherichia coli } \\
\text { Pseudomonas } \\
\text { aeruginosa }\end{array}$ & 42 & 1 & 0 \\
$\begin{array}{c}\text { Shigella boydii } \\
\text { Staphylococcus } \\
\text { aureus }\end{array}$ & 82 & 0.8 & 0 \\
$\begin{array}{c}\text { Streptococcus } \\
\text { faecalis }\end{array}$ & 57 & 1 & 0 \\
\hline
\end{tabular}

either by increasing the permeability of the cell membrane of the bacteria. The cell membrane causes loss or leakage of the contents of a cell of bacteria to the outside or through a direct link membrane of cell bacteria, causing the demise of polar membrane of bacteria, which leads to the death of a cell bacteria gradually. ${ }^{21,22}$

\section{CONCLUSION}

The results of the present study showed that the isolated alkaloids of the leaves of $E$. alba were effective against the bacterial species tested. This can be used to treat various diseases like pimples, food borne infections, typhoid, oral and throat sores and nosocomial infections. This investigation has opened up the possibility of the use of this plant for formulating a drug for human consumption possibly for the treatment of bacterial infections. These findings support the traditional knowledge of local users about their selection of this plant sample as antimicrobial agents and it is a preliminary scientific validation for the use of this plant for antibacterial activity. The results of the present study also support the medicinal usage of the alkaloids isolated from the leaves of $E$. alba can be used as antimicrobial agents in new drugs for therapy and can be subjected to identification and isolation of the therapeutic antimicrobials and undergo further pharmacological screening that can be used as sources for new drugs.

\section{ACKNOWLEDGEMENT}

The authors are thankful to Department of Microbiology, Kakatiya University, Warangal for providing test pathogens for carrying this work.

\section{CONFLICT OF INTEREST}

The authors declare that there is no conflict of interest, financial or otherwise regarding the publication of this paper.

\section{ABBREVIATION USED}

TLC: Thin layer chromatography; Rf: Retention factor; MIC: Minimal inhibitory concentrations, NCCLS: National Committee for Clinical Laboratory Standards; DMSO: Dimethyl sulfoxide; ANOVA: One-way analysis of variance.

\section{REFERENCES}

1. Shankar D, Ved DK. A Balanced Perspective for Management of Indian Medicinal Plants. Indian Forester. 2003;129(2):275-88.

2. Dalal S, Kataria SK, Sastry K, Rana SVS. Determination of Wedelolactone and Demethylwedelolactone in Eclipta alba (I) hassk by HPLC. Ethanobatanical Leaflets. 2010;14:248-58.

3. Roy RK, Mayank T, Dixit VK. Hair growth promoting activity of Eclipta alba in male albino rats. Arch Dermatol Res. 2008;300(7):357-64.

4. Saxena AK, Singh B, Anand KK. Hepatoprotective effects of Eclipta alba on subcellular levels in rats. J of Ehnopharmcology. 1993;40(3):155-61.

5. Wanger H, Geyer B, Kiso Y, Hikino H, Rao GS. Coumestans as the main active principles of the liver drugs Eclipta alba and Wedelia calendulaceae. Planta Med. 1986;52(5):370-74

6. Upadhyay RK, Pandey MB, Jha RN, Pandey VB. Eclalbatin, a triterpene saponin from Eclipta alba. J Asian Nat Prod Res. 2001;3(3):213-17.

7. Jadhav VM, Thorat RM, Kadam VJ, Salaskar KP. Chemical composition, pharmacological activities of Eclipta alba. J of Pharm Res. 2009;2(8):1129-231.

8. Khare CP. Encyclopedia of Indian Medicinal Plants. Springer Verlag Berlin Heidelberg New York. 2004;197-8.

9. Harborne JB. Phytochemical Methods: A Guide to Modern Techniques of Plant Analysis, Chapman \& Hall Ltd., London, UK, 1973.

10. Harborne J. Phytochemical methods: A guide to modern techniques of plant analysis. Chapman and Hall, London. 1984.

11. NCCLS. Performance standards for antimicrobial disk susceptibility testing, Twelfth Information Supplement. 2002.

12. Doughari JH, El-mahmood AM, Jyoyina I. Antimicrobial activity of leaf extracts of Senna obtusifolia (L). Af J Pharm and pharmacol. 2008;2(1):7-13.

13. Swapna G, Estari M. Medicinal Plants Used By Traditional Medicine Practitioners in the Management of HIV/AIDS-Related Diseases in Tribal Areas of Adilabad District, Telangana Region. The Ame J Sci \& Med Res. 2016;2(1):239-45.

14. Lenza VA, Morkel LJF, Coppede JS, Fernandes VC, Rossi NM, Franca SC, et al. Antimicrobial activities of ethanol extract and coumestans from Eclipta alba (L.) Hassk. (Asteraceae). Latin Am J Pharm. 2009;28:863-8.

15. Cowan MM. Plant products as antimicrobial agents. Clinical Microbiol Rev. 1999;12:564-82

16. Estari M, Rajendra PG. Phytochemical and antimicrobial activity of Acmella paniculata plant extracts. Journal of Bioinnovation. 2013;2(1):17-22.

17. Ahmed el-HM, Nour BY, Mohammed YG, Khalid HS. Antiplasmodial activity of some medicinal plants used in Sudanese folk-medicine. Env Health Insts. 2010;4(4):1-6.

18. Devi S, Devi GK, Thirumaran G, Arumugam A, Anantharaman P. Antibacterial activity of selected medicinal plants from Parangipettai coastal regions; southeast coast of India. World Appl Sci J. 2009;7(9):1212-5.

19. Feeny P. Inhibitory effect of Oak Leaf tannins on the hydrolysis of proteins by trypsine. J. Phytochem. 1998:8(11):2116.

20. Straus SK, Hancock RE. Mode of action of the new antibiotic for Gram-positive pathogens daptomycin, comparison with cationic antimicrobial peptides and lipopeptides. Biochem Acta. 2006:1758(9):1215-23.

21. Venkanna L, Estari M. Human Immunodeficiency Virus (HIV-1) Reverse Transcriptase inhibitory activity of Eclipta alba (L) leaves extracts. International Journal of Applied Biology and Pharmaceutical Technology. 2012;3(3):356-9.

22. Perez C, Pauli M, Bazerque P. An antibiotic assay by the agar-well diffusion method. Acta Biologiae et Medecine Experimentalis. 1990;15(1):113-5 


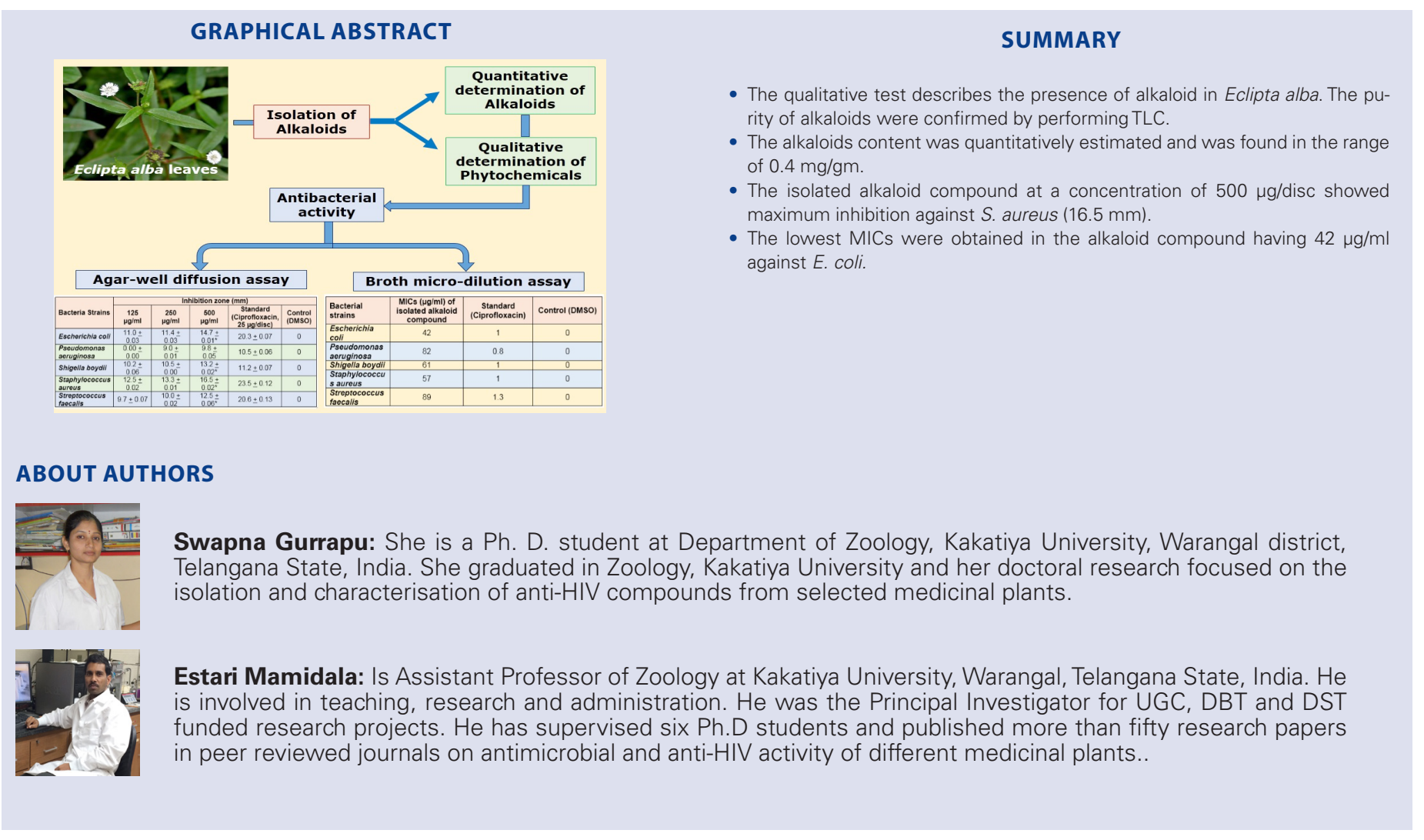

Cite this article: Gurrapu S, Mamidala E. In vitro antibacterial activity of alkaloids isolated from leaves of Eclipta alba against human pathogenic bacteria. Pharmacog J. 2017;9(4):573-7. 